\title{
Motives and barriers of Airbnb users: Findings from mixed-methods approach
}

\author{
Ghada Mohammed A. Ahmed \\ Prof Mohamed A. Ragheb \\ Passent Ibrahim Tantawi \\ Arab Academy for Science, Technology \& Maritime Transport \\ Alexandria, Egypt
}

\section{Keywords}

Airbnb, barriers, disruptive innovation, motives, sharing economy.

\begin{abstract}
Purpose: This study aims to investigate motives and barriers for Egyptian users to use Airbnb "as a platform of peer-to-peer accommodation instead of hotels" and how it affects the overall attitude towards Airbnb, behavioral intentions and actual usage of Airbnb.

Design/Methodology: A sequential mixed methods approach was adopted in this study and a comprehensive research model was adapted from both literature and results of qualitative phase and then tested via an online questionnaire.

Results/Findings: The findings revealed that motives: price, home benefits, privacy, and online reviews significantly explained the overall attitude towards Airbnb. In addition, the main barriers found were perceived risk and distrust, which can predict the overall attitude. Furthermore, from subjective norms, only social influence can predict behavioral intention to use Airbnb.

Theoretical and practical implications: This study contributes theoretically to the current literature by providing meaningful insights into the main motives of choosing Airbnb as accommodation other than traditional accommodations like hotels. Moreover, it deepens understanding regarding the barriers of not using Airbnb. The findings include several practical implications for industry. Hence, this study's conceptual effort provided a 'big' picture of how Airbnb consumers arrive at choosing (or not choosing) Airbnb for their trip. Additionally, the analytic effort of this study provided a holistic evaluation of the role of each motive and barrier. One critical question in this case is whether marketers should allocate an equal amount of resources to each variable or not. By assessing the importance of each variable, the researcher attempted to clarify the comparative importance of each variable in predicting purchase intentions and decision to use Airbnb.

Originality/value: This study fills the gap between the motives and barriers of Airbnb and their effect on overall attitude, behavioral intention and actual usage. Most previous studies focused only on the effect of motives and barriers on behavioral intentions without taking into consideration the actual usage. Similarly, previous studies focused on western contexts. However, this study focuses on one of the developing countries in the Middle East, Egypt, which has many travellers who are already using Airbnb. This study is considered one of the pioneer studies in this topic.
\end{abstract}

\section{Introduction}

During the past few years, a huge number of tourists chose not to stay in traditional forms of tourism accommodation, such as hotels. Instead, they preferred to stay in strangers' accommodations, which they found online via Airbnb. The idea of locals renting their houses informally to tourists had existed for centuries. However, new mobile and internet technologies have transformed this practice and allowed it to scale completely by facilitating virtual markets between hosts and guests where communication and trust are established (Guttentag, 2015). The rise of sharing economy affects the tourism and hospitality industry significantly (Zhu et al., 2017). Specifically, peer-to-peer business platforms such as Airbnb, which is considered a disruptive innovation that enables consumers to participate in collaborative consumption, where they can jointly share the underutilized assets such as rooms and cars (Botsman \& Rogers, 2010; Zervas et al., 2014).

Collaborative consumption is "a peer-to-peer-based activity of getting, giving, or sharing the access to certain products and services, organized through community-based online services (Hamari et 
al., 2016, p. 3). Airbnb is considered one of the most known examples of such consumption model; it provides an alternative way of renting short-term accommodations that vary from private rooms, entire homes to shared rooms (Zervas et al., 2014). When Airbnb was established in 2008, most people were uncertain about the idea of a business that based on tourists who pay in order to stay with strangers. In comparison with traditional accommodations, Airbnb residences show many clear weaknesses; the most obvious one is that guests have to trust a stranger, who is generally unlicensed. This stranger has to guarantee them the cleanliness, security, and quality of the place where they will sleep, instead of simply depending on a well-established accommodation with a well-known global brand.

As a result of the popularity of Airbnb, many researchers started to study the factors that may encourage or discourage users from choosing Airbnb (e.g. Guttentag, 2015, Guttentag, 2016; Tussyadiah 2015). A few numbers of academic researchers have started the process of exploring this question. Lamb (2011) used qualitative methods to investigate the motivations of CouchSurfing and Airbnb users. Guttentag (2015) introduced a conceptual review of Airbnb and its assumed key attractions from the perspective of disruptive innovation. Tussyadiah (2015) and Tussyaiah and Pesonen (2015) surveyed users of peer to peer short-term rentals (PSR) on their motives for using PSRs. They added analyses in the collaborative consumption literature. In addition, research of some (non-academic) researchers has also begun to explore why tourists choose Airbnb. Moreover, the tourism research company, Phocuswright, investigated the reasons beyond using PSRs by some users (Hennessey, 2014; Quinby \& Gasdia, 2014). Research arm of Morgan Stanley, a financial services company, conducted a consumer survey to investigate motivations for using Airbnb. This research was part of an investigation of the potential impacts of Airbnb on online travel agencies and hotels (Nowak et al., 2015). These studies highlight different reasons why tourists choose Airbnb, such as its low price and perceived authenticity, thereby providing some valuable initial insights into this line of inquiry.

Furthermore, past research on the sharing economy showed that the consumers' perceived value is a significant factor in determining their attitude and intention towards the innovation (Zhu et al., 2018). However, further studies found that there are other factors that can also motivate people to use peer-topeer accommodations. Other motives might be social benefits (Tussyadiah, 2016) and social interactions (Guttentag et al., 2017). This study aims to investigate the motives and barriers for Egyptian users to use Airbnb as a platform of peer-to-peer accommodation instead of other traditional accommodations such as hotels, the effect of those motives and barriers on the overall attitude towards Airbnb and how it affect the decision to use Airbnb.

\section{Literature Review \& Hypothesis Development 2.1 Motives of using Airbnb \\ 2.1.1 Price}

So et al. (2018) revealed that price is influential in determining how consumers perceived Airbnb as an alternative accommodation. Inspired from a previous study, Gong and Zheng (2018) found that price value has a significant influence on Chinese consumer's decision to use Airbnb. Moreover, Guttentag (2016) discovered that the low cost of Airbnb accommodations, in comparison to the cost of traditional accommodation, was the highest motive for using Airbnb. Furthermore, Rimer (2017) found that price is one of the most strongly agreed upon motivations for choosing Airbnb rather than other different forms of accommodations such as hotels.

\subsubsection{Home benefits}

Home benefits represent functional attributes of a home - 'household amenities,' ‘homely feel,' and 'large space" (Guttentag, 2016). Airbnb accommodations provide many benefits similar to those coming from a home environment. Some tourists may prefer the feeling of being at home while staying in a hotel as they can access practical residential amenities such as a full kitchen, a washing machine and a dryer (Guttentag, 2015). In So et al. (2018) study of motivations and constraints of Airbnb users, home benefits were influential in determining how consumers perceived Airbnb as an alternative accommodation. Unlike another study that was investigating the motivations and constraints of Chinese users, Gong and Zheng (2018) found that home benefits are insignificant in determining the users' decision to use Airbnb. Similarly, in an earlier study conducted to explore the motives and barriers to choose Airbnb, Guttentag 
(2015) concluded that the access to household amenities was considered the next most strongly agreed upon motive, he also found that the desire of users to feel at home and have a spacious house was very strong too. These findings are consistent with the findings of Phocuswright (Quinby \& Gasdia, 2014) and Morgan Stanley's studies (Nowak et al., 2015).

\subsubsection{Authenticity}

A number of past hospitality studies have highlighted the importance of authenticity as a motive for Airbnb users including Guttentag (2015) where he concluded that users have a strong desire to have authentic local experience but the importance of this factor was found to be lower than the importance of lower prices, household facilities and location convenience. However, when So et al. (2018) studied the effect of authenticity in the same model with other motives such as price and home benefits, he found that the effect of authenticity on both overall attitude towards Airbnb and behavioural intention seemed to be insignificant.

\subsubsection{Novelty}

Novelty is defined as travellers' personal feelings acquired from using non-standardized, individually tailored tourist goods and services. This is conceptually similar to what Mao and Lyu (2017) called unique experience. Guttentag (2016) concluded that travellers are encouraged to choose Airbnb by some degree of novelty-seeking. This finding was interesting to note because past tourism literature considered novelty-seeking from the perspective of destination choice instead of the accommodation choice.

\section{Ethos of sharing economy}

There are three key values of sharing economy, which Airbnb supports. These values are sustainability, local consumption, and trust between strangers (Botsman \& Rogers, 2010; Chase, 2015; Gansky, 2010; Pricewater house Cooper, 2015). Guttentag (2016) conducted a study to investigate the motives of using Airbnb and the ethos of sharing economy. He found that agreement with the three sharing economy items was quite neutral. Respondents showed minimal agreement concerning choosing Airbnb for its philosophy or because the money they spend goes directly to locals. They disagreed, on average, that they chose Airbnb because it is environmentally friendly. These findings are fairly consistent with Tussyadiah's (2015) research on PSRs, which also found that respondents' agreement level of sustainability factor was barely above neutral. It is also consistent with Kasim's (2004) finding, which stated that even tourists who pay attention to the issues of sustainability do not agree to pay more for an accommodation just to support those issues.

\subsubsection{Social Interaction}

When Stors and Kagermeier (2011) carried out a study to explore the motivations and expectations of Airbnb guests, they found that social interaction between hosts and guests can be assumed to be the "authentic" experience that certain travellers look for. Furthermore, in the study made by Tussyadiah and Pesonen (2016) who took their sample from American and Finnish travellers, they concluded that, among Finnish travellers, older consumers seek social appeal greatly when considering Airbnb. However, Gong and Zheng (2018) found that social interactions are insignificant in determining the motives and barriers for using Airbnb for Chinese users. This result was consistent with that of So et al. (2018), which also found that the relative importance of social interaction appeared to be negligible.

\subsubsection{Online reviews}

Online reviews became a standard attribute for many consumer-facing online services as it provides potential customers with useful information about products and services (Engler et al., 2015). From the consumers' perspective, the travel experience entails three phases: anticipation, experience, and reflection. Based on these three phases, travellers gather information, make travel decisions, and manage their travel plans (Bae et al., 2017). Moreover, Goldsmith and Horowitz (2006) pointed out that consumers frequently seek out the opinions of other consumers online to reduce the risk of expectation failure (Kirmani and Rao, 2000). In recent years, online reviews have become a critical concern in the hospitality industry with key factors including review quality, quantity and consistency (Xie et al., 2016). 
Based on the above discussion, the researcher formulated the first main hypotheses and its subhypotheses as follows:

The following research hypotheses will be tested:

H1: Motives that positively affect the individual's overall attitude towards Airbnb.

H1.1: Price affects the individual's overall attitude towards Airbnb positively.

H1.2: Home benefits affect the overall attitude towards Airbnb positively.

H1.3: Authenticity affects the overall attitude towards Airbnb positively.

H1.4: Novelty affects the overall attitude towards Airbnb positively.

H1.5: The ethos of sharing economy affects individuals 'overall attitude towards Airbnb positively.

H1.6: Social interactions affect individuals 'overall attitude towards Airbnb positively.

H1.7: Online reviews affect individuals' overall attitude towards Airbnb positively.

H1.8: Privacy affects individuals' overall attitude towards Airbnb positively.

\subsection{Barriers of using Airbnb}

\subsubsection{Perceived risk}

Perceived risk is defined as uncertainty felt regarding possible negative consequences of consuming a product or service (Featherman \& Pavlou, 2003). Mao and Lyu (2017) defined perceived risk accompanied with Airbnb as a subjective expectation of a potential loss when searching for a required result. So et al. (2018) found that perceived risk had no significant relationship, in a relative sense, to attitude or behavioral intentions. Moreover, Gong and Zheng (2018) concluded that perceived risk is insignificant in choosing Airbnb. However, some previous studies supported the negative effect of perceived risk on attitude (Mao \& Lyu, 2017) and repurchase intention (Liang, 2015).

\subsubsection{Distrust}

Trust in the context of Airbnb means accepting a position of vulnerability and trusting that the exchange partner will fulfil his or her part (Satama, 2014). Olson (2013) found that consumers' perceived fears about participating in the sharing economy were the main barrier to participate in collaborative consumption. Furthermore, so et al. (2018) found that distrust appeared one of the most important obstacles that negatively affects the consumers' overall attitude towards Airbnb. Tussyadiah and Pesonen (2016) were in line with this result. Moreover, Sthapit and Björk (2019) investigated 213 negative reviews of Airbnb users and they concluded two major themes that reflect the sources of distrust: Airbnb's poor customer service and the hosts' unpleasant behaviour.

\subsubsection{Insecurity}

So et al. (2018) investigated the effect of insecurity on users' intentions when deciding to use Airbnb and they concluded that consumers' perceived insecurity of Airbnb accommodation undermined purchase-related responses. After Lyu et al. (2019) interviewed 34 users of Airbnb, he found that peer-topeer (P2P) users are more concerned about the safety issues, especially that the operators of P2P accommodation have shifted from business entities to ordinary individuals. Based on the above discussion, the researcher formulated the second main hypothesis and its sub-hypotheses as follows:

\section{H2: Barriers negatively affecting the individuals' overall attitude towards Airbnb.}

H2.1: Perceived risk affects individuals' overall attitude towards Airbnb negatively.

H2.2: Distrust affects individuals' overall attitude towards Airbnb negatively.

H2.3: Insecurity affects individuals' overall attitude towards Airbnb negatively.

The literature also mentioned two additional theoretical concepts, which are relevant to the same concept. They were two factors of subjective norms found to affect the adoption of Airbnb: social influence and trend affinity. Social influence represents the extent to which the consumer's close community, such as friends and family, believe he or she should use a certain product or innovation (Venkatesh et al., 2012). Similarly, given that the sharing economy or collaborative consumption model is emerging as a new trend, which changes consumers' planning and actual travel behaviour (Tussyadiah \& Pesonen, 2016b). Another important form of subjective norms is trend affinity. Trend affinity occurs when the consumer wishes to follow such a trend or seeks to use innovative and fashionable products and services such as Airbnb (Möhlmann, 2015). Additionally, sustainability, which reflects the belief that 
collaborative consumption may reduce the development of new products and the use of raw materials, as well as support the local community and economy, could also affect the consumer's decision to choose Airbnb (Tussyadiah \& Pesonen, 2016a). Related to sustainability is the ethos of sharing economy, which represents the line of thought of money spent to locals, environmental friendliness and the philosophy of Airbnb that supports the community's wellbeing (Guttentag et al., 2017). Mao and Lyu (2017) also found the significance of word-of-mouth communications on consumer attitude toward Airbnb.

Based on the above discussion, the researcher formulated the third, fourth and fifth main hypothesis and its sub-hypotheses as following:

H3: Overall attitude towards Airbnb affects the behavioral intention to use Airbnb.

H4: Subjective norms affect overall attitude towards Airbnb positively.

H4.1: Trend affinity affects overall attitude towards Airbnb positively.

H4.2: Social influence affects overall attitude towards Airbnb positively.

H5: Subjective norms affect behavioral intentions to use Airbnb positively.

H5.1: Trend affinity affects behavioral intentions to use Airbnb positively.

H5.2: Social influence affects behavioral intentions to use Airbnb positively.

H6: Behavioural intentions to use Airbnb affect actual usage of Airbnb.

\section{Research Methodology}

\subsection{Introduction}

The concept of sharing economy is relatively new, and Airbnb existed only since 2008. This created a gap in the literature related to this topic and there is a need to explore the motives and barriers for Egyptian users to use Airbnb. Since there are few studies carried out in Egypt, this study may enhance the literature in this topic, and it will try to answer many important questions. The research questions of this thesis will be answered by conducting an empirical study. The empirical study involves a survey based on a combination of qualitative and quantitative methods. The qualitative method (phase 1) consists of semistructured interviews with some Airbnb users and the quantitative method (phase 2) consists of an online questionnaire.

\subsection{Qualitative study}

To address the scarcity and fragmented nature of current research on sharing economy and Airbnb, the researcher used sequential mixed-methods design to gain an in-depth understanding of the motives and barriers for Egyptian users to use Airbnb as a platform of peer-to-peer accommodation instead of hotels and to quantify the extent to which related attitudes or behaviours occur (Coulter et al., 2003; McDonald, 2011).

Overall, the lack of empirical, in-depth research into the facets of Airbnb, as there are very few studies made in Egypt, necessitates an interpretative, discovery-oriented approach to capture deep insights into the motives and barriers for Egyptian users.

The researcher conducted semi-structured interviews with open-ended questions with some users of Airbnb. The main objective of these interviews was to investigate the main motives of choosing Airbnb in their trips and the main barriers that might prevent them from using it. There were different communication means of conducting interviews such as face-to-face, mobile calls and WhatsApp. Interviews (phase 1) were conducted with a total purposive sample of 8 users and all were digitally recorded, upon the respondent's consent. The average time of each interview ranged from $20-40$ minutes.

\subsection{Survey instrument and sample}

The primary purpose of quantitative method (Study Phase 2) was to construct and validate a survey questionnaire reflecting the qualitative results from Study Phase 1 that could be used to explore the motives and barriers to use Airbnb for Egyptian users. Moreover, the modified research model was investigated with a convenience sample (i.e. 435) of the second phase of this study. An online survey was conducted, and the sample was formed from some Facebook travelling experience groups, which contained Egyptian members. The admins sent members invitations to answer the questionnaire. For the Exploratory Sequential Design, according to Creswell (2014), Study Phase 2 needed to use a different 
sample, but from among the same population as Study Phase 1. The survey period started on 15th November until 31st December 2019. A total of 435 of completed and valid responses were collected.

The questionnaire was mainly divided into three sections; the first section consisted of one screening question, which asked the participants if they have used Airbnb before. The objective of this question is to guarantee that the respondents are users only. The second section included demographic questions like age, income, and education level. It also included three questions about the last trip, which were: the main purpose of it, the type of the accommodation used and the overall level of satisfaction of this experience. The third section of the questionnaire contained a group of questions that measure each of the research variables based on the scales used in the literature from the previous studies. All of those questions are 5-point Likert scale questions ranging from 1 as strongly disagree to 5 as strongly agree.

\subsubsection{Variables measurement}

To measure the motives and barriers of using Airbnb, 58 questions were posed to respondents. These questions are related to 10 different motives: price, home benefits, privacy, authenticity, novelty, ethos of sharing economy, social interactions, online reviews, social influence, and trend affinity. Furthermore, they include questions of the three different barriers, which are perceived risk, distrust, and insecurity. Moreover, they include questions that measure two mediators, which are overall attitude towards Airbnb, behavioral intention towards Airbnb and actual usage as one dependent variable.

\subsubsection{Measurement instrument}

The literature suggested validated scales for use in this study, ensuring initial reliability and validity of our measurement. Specifically, four items originating from Sweeney and Soutar (2001) were adapted from Walsh et al. (2014) to measure price value. While four items from Guttentag et al. (2017) measured authenticity, four items from Guttentag (2016) captured novelty and three items from (Stors and Kagermeier, 2015) and Tussyadiah (2015, pp. 817-830) measured social interactions. Three items following Guttentag (2016) measured home benefits while four items following Möhlmann (2015) and Moeller and Wittkowski (2010) measured trend affinity.

Four items borrowed from Nysveen et al., (2005), Moore and Benbasat (1991), and Venkatesh et al. (2012) gauged social influence. Three items adapted from Tussyadiah's (2015) were used to measure ethos of sharing economy. Moreover, three measures used for online reviews which were adapted from Chen and Chang (2018).

Moreover, privacy was measured by three questions adapted from (Zhang et al., 2019). Four items based on Featherman and Pavlou (2003) measured perceived risk. While insecurity was measured using a scale from Yang, Jun, and Peterson (2004), two items measuring distrust were adapted from Tussyadiah and Pesonen (2016a). Three items adapted from Francis et al. (2004) and Li et al. (2018b) measured behavioral intentions. Overall attitude was measured using the scale from MacKenzie, Lutz, and Belch (1986). In addition, actual usage was measured using four questions adapted from Al-Qeisi and Hegazy (2015). All questions were backtranslated into Arabic before distributing among users.

\subsubsection{Data analysis}

Using content analysis, the data obtained from the eight interviewees were analyzed to extract the word frequency table, word cloud and tree mapping using Nvivo program for qualitative analysis. Before empirically testing the proposed framework in Study Phase 2, the researcher conducted Exploratory Factor Analysis (EFA) by using Statistical Package for the Social Sciences (SPSS25) on a small sample (30 users) in order to measure the validity and reliability of the used measures before distributing the main sample. The following results were concluded as:

Cronbach's alpha values were employed as the assessment of the scales' reliability. Reliability coefficients ranged from 0.7 to 0.9 , which is acceptable. When it comes to measuring validity, it was found that in most variables $\mathrm{KMO}>0.5$, Loading factor $>0.5$, AVE $>0.5$ and Bartlett's Test of Sphericity sig. < 0.05 .

Those results mean that the model variables have a high degree of reliability and validity. 
Findings/Results

4.1. Results of study phase 1 (qualitative phase)

Motives

$1^{\text {st }}$ question: What motivates you to use Airbnb rather than hotels?

Theme one: price and home benefits are the two main aspects that the majority of interviewees agreed upon.

Cheaper prices of accommodations on Airbnb are an advantage that attracts individuals to use the application for reservation. Hotel prices are more expensive than that of Airbnb. Likewise, home benefits are one of the motives that influence users. To feel like home, to have kitchen and feel free to cook, especially on long trips, are considered as an advantage as not all hotels have this advantage. Therefore, it will be very expensive to order a meal every day. For example, one of the interviewees said: "The first thing that motivates me is that I can choose a good place for a reasonable price (the most important reason)". Another interviewee said: "Since I travel a lot and I almost stay for long periods, I prefer to use Airbnb because of its reasonable price, which is lower than hotels and the kitchen! I prefer to cook my own food, especially when I stay for long periods and it gave me more privacy".

On the other hand, some mentioned that social influence, like recommending the application by their friends and family members, and privacy as important aspects. For instance, one of the interviewees quoted: "At first, it was because my friends advised me but after trying it, my first experience turned out to be positive. So, I decided to use it again".

Figure 4.1 illustrates the different motives for people to use Airbnb application when traveling. On the one hand, it could be noticed that the major motives are price and home benefits, while privacy and social influence are mentioned by some of them as motives as well.

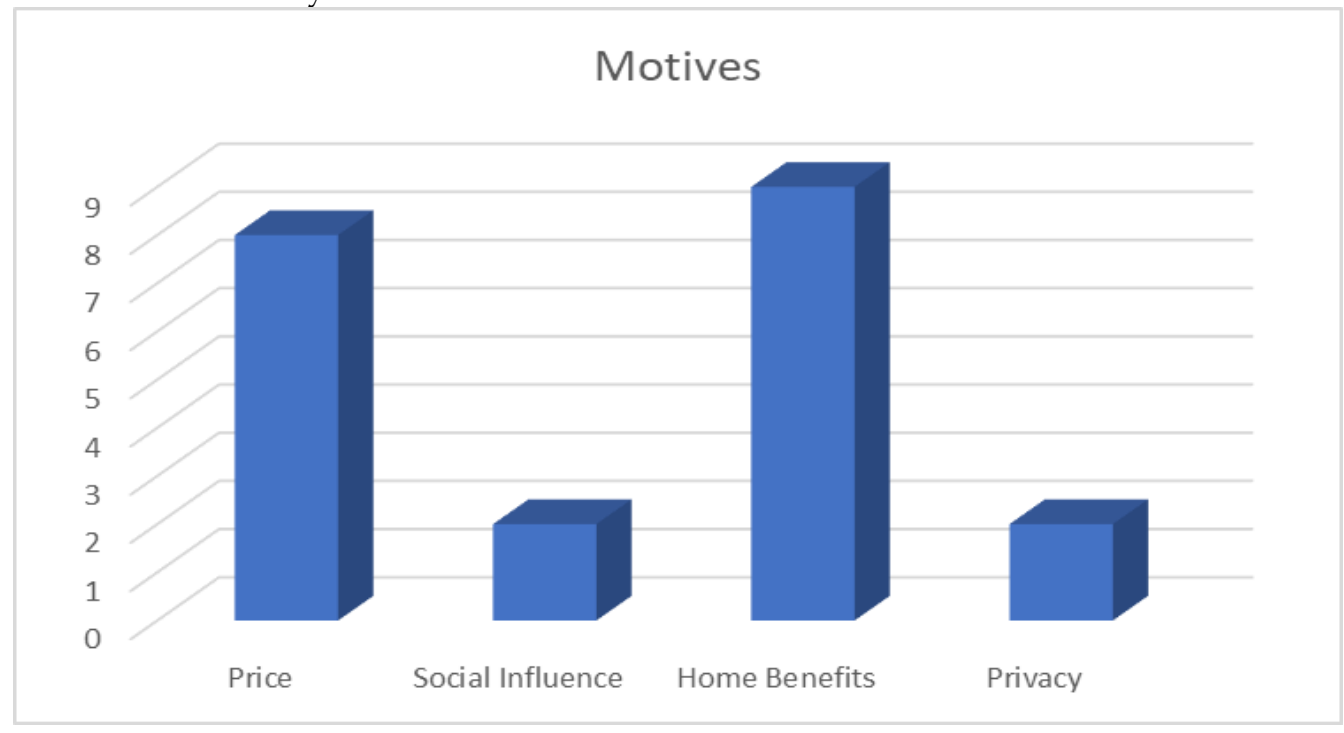

Barriers:

Figure 4-1: Motives behind using Airbnb

$2^{\text {nd }}$ question: "What did you dislike about Airbnb?"

The minority dislikes the host they meet; they may be unfriendly and difficult to deal with. Few said that there should be voice-calls to communicate more with the host. Others say that the location of the house is not precise until you pay but this issue is for the security of the host. Moreover, some say that it is difficult to change the date of reservation or cancel it. Otherwise, the rest of the interviewees completely agree that Airbnb is perfect.

For example, one of the interviewees said:

"Communication. I think there should be more tools of communication between users and hosts like voice calls which make communication easier".

While another said:

"Until now, nothing is negative with the service". 


\subsection{Results of study phase 2 (quantitative phase)}

Although the researcher investigated the validity and reliability in the pilot study phase, the researcher conducted validity and reliability tests for the main sample to confirm that the variables are both valid and reliable. The tests were conducted using SPSS25. The results of EFA show that loading factor for all the variables was greater than 0.5 . AVE $\%$ is greater than $70 \%$ for all the variables and $\mathrm{KMO}$ exceeds $50 \%$ for all the variables and finally Bartlett's test resulted in p-value $<0.05$ for all the variables, which is significant. Similarly, Cronbach's alpha for all of the variables exceeded $70 \%$. Bagozzi and Kimmel (1995) suggest Cronbach's alpha values should be greater than 0.7. Each of the constructs' Cronbach's Alpha score was acceptable based on the greater than 0.7 cut-off established by Nunnally (1978). Additionally, Bagozzi and Kimmel (1995) state that levels above 0.6 are acceptable and show acceptable composite reliability but they suggest 0.7 as a better cutoff level.

Table 4.1 contains all direct effects, its standardized estimate, and the decision at $5 \%$ level. It shows the effect of each motive and barrier on the overall attitude towards Airbnb, the effect of the overall attitude towards Airbnb on the behavioral intention and the effect of behavioral intentions on actual usage. It was found that price, privacy, and online reviews have a significant and positive effect on overall attitude towards Airbnb, which means thatH1.1, H1.7 and H1.8 are acceptable. Contrary to the prediction in hypothesis H1.2, which assumes that home benefits positively affect overall attitude towards Airbnb, it was concluded that home benefits have a negative and a significant effect on the overall attitude towards Airbnb. Therefore, this hypothesis is rejected. Moreover, the remaining motives including authenticity, novelty, ethos of sharing economy and social interactions don't have a significant effect on overall attitude towards Airbnb. As such, the hypotheses H1.3, H1.4, H1.5 and H1.6 are rejected.

The subjective norms, which include trend affinity and social influence, were tested too to investigate their effect on both overall attitude towards Airbnb and behavioral intention to use it. It was found that only social influence has a significant and positive effect on behavioral intention to use Airbnb, which means H5.2 is acceptable and H5.1, H4.1 and H4.2 are rejected. Furthermore, three barriers were investigated to test their effect on the overall attitude towards Airbnb and it was concluded that both perceived risk and distrust have negative and significant effect on the overall attitude towards Airbnb, which means accepting hypotheses $\mathrm{H} 2.1$ and H2.2 and rejecting H2.3. In addition to those relations, hypothesis 3 and hypothesis 6 were tested. It was found that there is a positive and significant effect on the overall attitude towards Airbnb regarding behavioral intention and the effect of behavioral intention concerning actual usage, which supports both hypotheses. Figure 4.1 shows all the direct relations.

Table 4.1 Direct effects and its standardized estimate and the decision at $5 \%$ level

\begin{tabular}{|c|c|c|c|c|c|c|}
\hline \multicolumn{2}{|c|}{} & $\begin{array}{c}\text { Standardized Regression } \\
\text { Weights }\end{array}$ & $\begin{array}{c}\text { Standard } \\
\text { Errors }\end{array}$ & $\begin{array}{c}\text { P- } \\
\text { Value }\end{array}$ & $\begin{array}{c}\text { Decision at } \\
\text { significant } \\
\text { level 5\% }\end{array}$ \\
\hline \multicolumn{2}{|c|}{ Direct Effects } & \multicolumn{3}{c|}{} \\
\hline Attitude & $<--$ & Online & \multicolumn{2}{c|}{} \\
\hline Attitude & $<--$ & Interactions & 0.0574 & 0.018 & 0.000 & Accept \\
\hline Attitude & $<--$ & Ethos of & 0.047 & 0.024 & 0.066 & Reject \\
\hline Attitude & $<--$ & Novelty & -0.055 & 0.030 & 0.132 & Reject \\
\hline Attitude & $<--$ & Authenticity & 0.035 & 0.025 & 0.076 & Reject \\
\hline Attitude & $<--$ & Privacy & 0.167 & 0.021 & 0.257 & Reject \\
\hline Attitude & $<--$ & Home & -0.106 & 0.020 & 0.000 & Accept \\
\hline Attitude & $<--$ & Price & 0.193 & 0.020 & 0.000 & Accept \\
\hline Attitude & $<--$ & Perceived & -0.595 & 0.023 & 0.000 & Accept \\
\hline attitude & $<--$ & insecurity & 0.015 & 0.020 & 0.000 & Accept \\
\hline attitude & $<--$ & distrust & -0.087 & 0.019 & 0.618 & Reject \\
\hline attitude & $<--$ & Social & 0.002 & 0.020 & 0.005 & Accept \\
\hline attitude & $<--$ & Trend & 0.053 & 0.033 & 0.954 & Reject \\
\hline intention & $<--$ & Social & 0.107 & 0.030 & 0.083 & Reject \\
\hline intention & $<--$ & Trend & -0.011 & 0.044 & 0.000 & Accept \\
\hline intention & $<--$ & Overall & 0.813 & 0.041 & 0.705 & Reject \\
\hline usage & $<--$ & intention & 0.930 & 0.046 & 0.000 & Accept \\
\hline
\end{tabular}




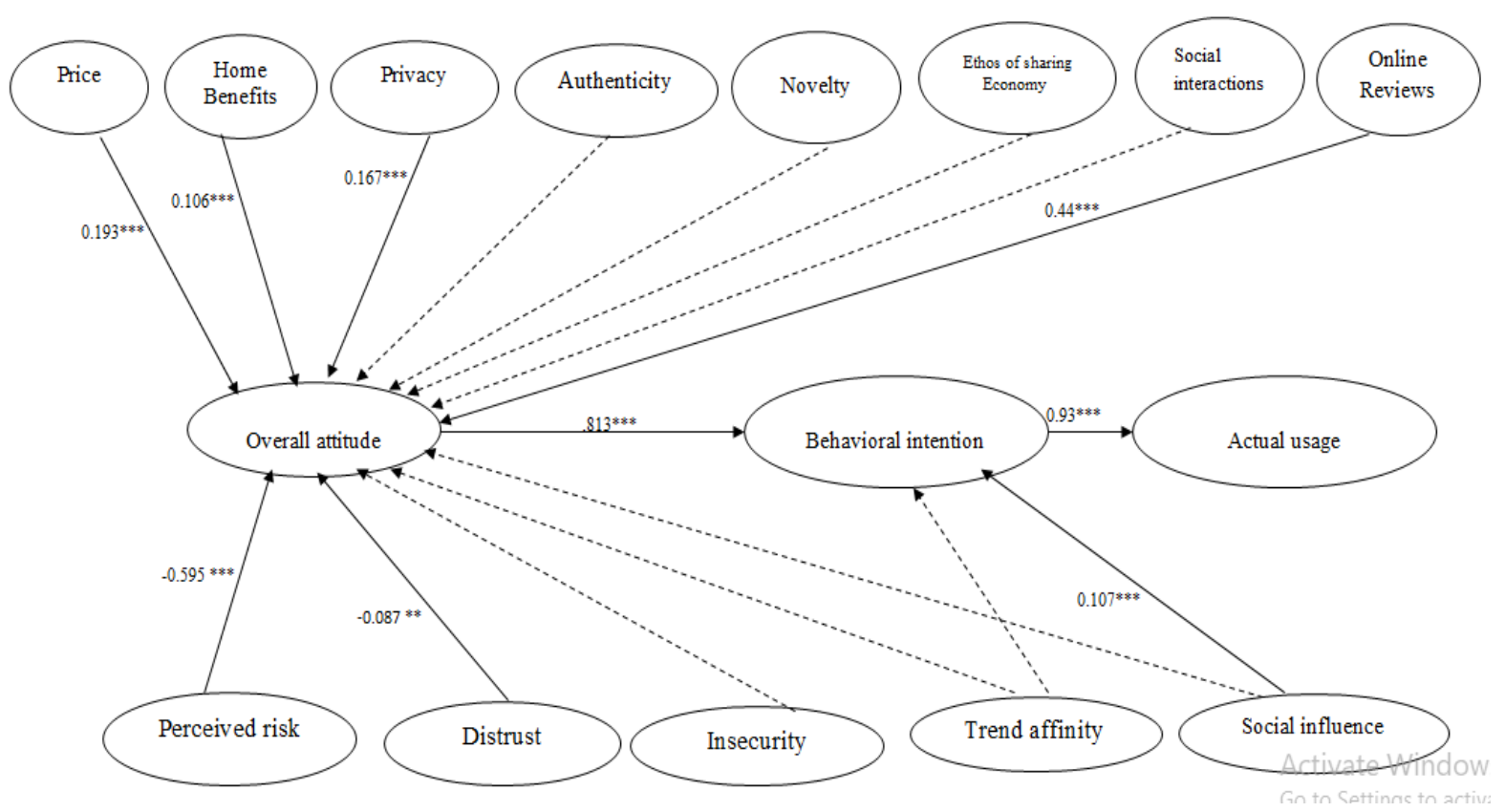

*** $\mathrm{p}<0.001,{ }^{* *} \mathrm{p}<0.01$, solid line $=$ significant path, dotted line $=$ non-significant $\mathrm{path}$

Figure 4.2 Results of the Inner Model

In order to decide whether to accept or reject the research model according to Amos, the following tests were conducted and table 4.2 below indicates the results of these tests. Generally, it is an acceptable model.

\section{Table 4.2}

\begin{tabular}{|r|r|l|}
\hline \multicolumn{1}{|c|}{ Criterion } & 0ptimal range & Estimate \\
\hline relative chi-square $\left(\chi^{2} /\right.$ d.f) & 1.3 acceptable fit , 3.5 reasonable fit & 3.891 \\
\hline goodness of fit index (GFI) & $>0.90 \mathrm{~A}$ value of 1 indicates a perfect fit & 0.923 \\
\hline Tucker-Lewis coefficient (TLI) & $>0.90 \mathrm{TLI}$ values close to 1 indicate a very good fit & 0.911 \\
\hline comparative fit index (CFI) & $>90 \mathrm{CFI}$ values close to 1 indicate a very good fit & 0.944 \\
\hline root mean square error (RMSEA) & $0=$ exact fit $<0.05$ good fit,$<0.08$ reasonable fit & 0.078 \\
\hline
\end{tabular}

\section{Discussion and conclusion}

\section{Conclusion}

From the statistical analysis in the previous section, the results are as follows:

H1: Motives that positively affect the individual's overall attitude towards Airbnb.

Price, privacy, and online reviews had a positive effect on the overall attitude towards Airbnb. This result is consistent with Gong and Zheng (2018), Rimer (2017), Mayseri et al. (2017) and Tussyadiah and Pesonen (2016). While the results found that home benefits affect the overall attitude of the users towards Airbnb negatively, this result is inconsistent with the results of So et al. (2018), Guttentag (2015), Nowak et al. (2015) and (Quinby and Gasdia, 2014). Regarding other motives such as authenticity, novelty and social interactions, the results revealed that these motives don't have any significant effect on the overall attitude of the users, which is consistent with the results of studies made by So et al. (2018) and Gong and Zheng (2018). On the other hand, it is inconsistent with other studies conducted by Guttentag $(2015,2016)$ and Lamb (2011), which found that these motives were significant and important factors when it comes to 
choosing Airbnb. Furthermore, ethos of sharing economy was found to be insignificant in deciding to use Airbnb. These results are in line with studies of Guttentag (2016) and Tussyadiah (2015).

H2: Barriers negatively affecting the individuals' overall attitude towards Airbnb.

The results found that perceived risk and distrust have a negative and a significant effect on the overall attitude towards Airbnb. These are the only two barriers that turned out to be significant. This result is consistent with the findings of So et al. (2018), Tussyadiah and Pesonen (2016) and (Sthapit and Bjork, 2019). In addition, insecurity turned out to be insignificant as a barrier that discourages using Airbnb and it has no effect on deciding to use Airbnb. This result is inconsistent with the findings of So et al. (2018) and Lyu et al. (2019).

H3: Overall attitude towards Airbnb affects the behavioral intention to use Airbnb. This hypothesis is accepted.

H4: Subjective norms positively affect overall attitude towards Airbnb. This hypothesis is rejected.

H5: Subjective norms positively affect overall attitude towards Airbnb.

It was concluded that social influence only positively affects behavioural intentions to use Airbnb. On the one hand, this result is consistent with results of So et al. (2018) and Mao and Lyu (2017). On the other hand, trend affinity was found to be insignificant, which is inconsistent with the results of those two past studies.

H6: Behavioral intentions to use Airbnb affect actual usage of Airbnb. This hypothesis has been accepted.

\section{Theoretical and practical implications}

This study contributes theoretically to the current literature by providing meaningful insights into the main motives of choosing Airbnb as accommodation instead of traditional accommodations like hotels. Moreover, it helps in understanding more about the barriers of not using Airbnb. From the qualitative phase, a new motive has been found. This motive is privacy, which affects the overall attitude towards Airbnb and, in return, affects the decision to use Airbnb. In past literature, no one studied the effect of this variable as one of the motives that encourage users to use Airbnb. In reality, it turned out to be an important motive. This finding contributes in a theoretically meaningful way to the current literature because it turned out to have a significant effect on the overall attitude towards Airbnb after testing it in the quantitative phase.

Some of the practical implications include some specific aspects of this study results. For example, the significant effect of price suggests that, in the peer-to-peer accommodation sector, developing a value for money product is of great significance. Furthermore, the significant effect of online reviews shows the importance of word of mouth and how powerful it is in encouraging or discouraging potential customers. Factors arising from the social environment, such as social influence, could also affect consumers' intentions to adopt Airbnb. Finally, perceived risk and distrust were found to be the only two barriers that significantly influence consumers' overall attitude. This finding highlights a need for individual hosts of peer-to-peer accommodation as well as platform companies, such as Airbnb, to establish trust with consumers through not only better quality assurance or satisfaction guarantee mechanisms, but also through a consistent provision of superior accommodation experiences that exceed expectations. As in the traditional lodging industry, trust-based consumer relations in addition to delightful accommodation experiences beyond expectations are likely to generate positive referrals and word-of-mouth communications. This study may serve as a practical reference for practitioners as well as researchers when developing programs and strategies to manage Airbnb consumers' needs and decision process.

\section{Limitations and future research}

While evaluating the significant findings of this study, a number of limitations should be acknowledged. First, this study based mainly on a sample collected via online platforms through Facebook travelling groups that have only Egyptian users, which means that the findings cannot be generalized on all travellers. Future research could sample users from different countries and cultures to determine whether the model is equally valid and useful in other research settings. In addition, the sample that was used to make interviews was small, it consisted of 8 users only as it was very difficult to 
reach more users for interviews and a purposive sampling technique was used. This information cannot be generalized and that is why further studies need to increase the sample size in the qualitative phase. Moreover, the motives beyond using Airbnb are somewhat similar to those of using Bed \& Breakfast, Couchsurfing, and hostels. As such, it will be useful to compare the motives of Airbnb users with the motives of users of other three accommodations.

\section{References}

Al-Qeisi, K. and Hegazy, A. (2015), “Consumer Online Behaviour: A perspective on Internet Banking Usage in Three Non-western Countries", Procedia Economics and Finance, available at: https://doi.org/10.1016/s22125671(15)00347-0.

Bae, S.J., Lee, H., Suh, E.K. and Suh, K.S., 2017. Shared experience in pretrip and experience sharing in posttrip: A survey of Airbnb users. Information \& Management, 54(6), pp.714-727.

Bagozzi, R. P., \& Kimmel, S. K. (1995). A comparison of leading theories for the prediction of goal-directed behaviours. British Journal of Social Psychology, 34(4), 437-461.

Botsman, R. and Rogers, R.C.N.-O.L.S. (STACK) H. C.B. 2010. (2010), "The Rise of Collaborative Consumption", What's Mine Is Yours: How Collaborative Consumption Is Changing the Way We Live.

Burr, T.L., Coulter, C.A., Howell, J. and Wangen, L.E., 2003. Solution monitoring: quantitative and qualitative benefits to nuclear safeguards. Journal of nuclear science and technology, 40(4), pp.256-263.

Chase, R. (2015). Peers Inc.: How people and platforms are inventing the collaborative economy and reinventing capitalism. New York, NY: Public Affairs.

Chen, C.C. and Chang, Y.C. (2018), “What drives purchase intention on Airbnb? Perspectives of consumer reviews, information quality, and media richness", Telematics and Informatics, Elsevier, Vol. 35 No. 5, pp. 1512-1523.

Coulter, Robin \& Price, Linda \& Feick, Lawrence. (2003). 2003), "Rethinking Origins of Involvement and Brand Commitment: Insights from Postsocialist Central Europe. Journal of Consumer Research. 30. 151-69. $10.1086 / 376809$.

Creswell J. 2014. Research design: qualitative, quantitative, and mixed methods approaches. Thousand Oaks: SAGE

Elizabeth McDonald, K. (2011), “Transcultural wellness: An exploratory study”, Journal of Multicultural Counseling and Development, available at: https://doi.org/10.1002/j.2161-1912.2011.tb00638.x.

Engler, T.H., Winter, P. and Schulz, M., 2015. Understanding online product ratings: A customer satisfaction model. Journal of Retailing and Consumer Services, 27, pp.113-120.

Featherman, M.S. and Pavlou, P.A., 2003. Predicting e-services adoption: a perceived risk facets perspective. International journal of human-computer studies, 59(4), pp.451-474.

Francis, J. J., Eccles, M. P., Johnston, M., Walker, A., Grimshaw, J., Foy, R., et al. (2004). Constructing questionnaires based on the theory of planned behavior: A manual for health services researchers. Centre for Health Services Research: Newcastle Upon Tyne, United Kingdom. Retrieved January 25, 2007, from http:/ / www.rebeqi.org/ViewFile.aspx?itemID=212.

Gansky, L. (2010). The mesh: Why the future of business is sharing. New York, NY: Penguin.

Goldsmith, R.E., Horowitz, D., 2006. Measuring motivations for online opinion seeking. J. Interactive Advertis. 6 (2), 2-14.

Gong, J., \& Zheng, Y. 2018. A study on the motivation and constrain factors influence Chinese travelers' attitude towards Airbnb.

Guttentag, D. (2016), “Why tourists choose Airbnb: A motivation-based segmentation study underpinned by innovation concepts", Journal of Travel Research, available at: https://doi.org/10.1177/0047287517696980.

Guttentag, D. 2015. Airbnb: disruptive innovation and the rise of an informal tourism accommodation sector. Current issues in Tourism, 18(12), 1192-1217.

Guttentag, D.A. and Smith, S.L.J. (2017), “Assessing Airbnb as a disruptive innovation relative to hotelsSubstitution and comparative performance expectations", International Journal of Hospitality Management, available at: https://doi.org/10.1016/j.ijhm.2017.02.003.

Hamari, J., Sjöklint, M., \& Ukkonen, A. 2016. The sharing economy: Why people participate in collaborative consumption. Journal of the association for information science and technology, 67(9), 2047-2059.

Hennessey, S. 2014. An Inside View of Airbnb in New York City. Hotel News Now.

Kasim, A. (2004). Socio-environmentally responsible hotel business: Do tourists to Penang Island, Malaysia care? Journal of Hospitality \& Leisure Marketing, 11(4), 5-28.

Kirmani, A., Rao, A.R., 2000. No pain, no gain: a critical review of the literature on signaling unobservable product quality. J. Market. 64 (2), 66-79.

Lamb, Z. 2011. Rethinking authenticity in tourist experience: Analyzing the motivations of travelers in person-toperson hospitality networks. Unpublished master's thesis). The University of Chicago, Chicago, IL. 
Li, H., Schein, D.D., Ravi, S.P., Song, W. and Gu, Y. (2018), “Factors influencing residents' perceptions, attitudes and behavioral intention toward festivals and special events: A pre-event perspective", Journal of Business Economics and Management, available at: https://doi.org/10.3846/jbem.2018.5536.

Liang, L.J., 2015. Understanding repurchase intention of Airbnb consumers: perceived authenticity, EWoM and price sensitivity.

Lu, L. and Tabari, S., 2019. Impact of Airbnb on customers' behavior in the UK hotel industry. Tourism Analysis, 24(1), pp.13-26.

Lyu, J., Li, M. and Law, R. (2019), "Experiencing P2P accommodations: Anecdotes from Chinese customers", International Journal of Hospitality Management, available at: https://doi.org/10.1016/j.ijhm.2018.07.012.

MacKenzie, S.B., Lutz, R.J., and Belch, G.E. (1986), “The Role of Attitude toward the Ad as a Mediator of Advertising Effectiveness: A Test of Competing Explanations", Journal of Marketing Research, available at: https://doi.org/10.2307/3151660.

Mao, Z. and Lyu, J., 2017. Why travelers use Airbnb again? International Journal of Contemporary Hospitality Management.

Mayasari, Iin \& Chris, Handrix \& Wiadi, Iyus. (2017). The Qualitative Analysis of Motivational Factors of The Airbnb As Collaborative Consumption in The Era of Economic Sharing.

Moeller, S., \& Wittkowski, K. (2010). The burdens of ownership: Reasons for preferring renting. Managing Service Quality: An International Journal, 20(2), 176e191.

Möhlmann, M., 2015. Collaborative consumption: determinants of satisfaction and the likelihood of using a sharing economy option again. Journal of Consumer Behaviour, 14(3), pp.193-207.

Moore, G.C. and Benbasat, I. (1991), “Development of an instrument to measure the perceptions of adopting an information technology innovation", Information Systems Research, available at: https://doi.org/10.1287/isre.2.3.192.

Nowak, B., Allen, T., Rollo, J., Lewis, V., He, L., Chen, A., ... \& Savino, M. 2015. Global insight: Who will Airbnb hurt more-hotels or OTAs. Morgan Stanley Research, 232-244.

Nunnally, J. (1978), Psychometric Theory (2nd Ed), Journal of Chemical Information and Modeling, available at: https://doi.org/10.1017/CBO9781107415324.004.

Nysveen, H., Pedersen, P.E. and Thorbjørnsen, H. (2005), “Intentions to use mobile services: Antecedents and crossservice comparisons", Journal of the Academy of Marketing Science, available at: https://doi.org/10.1177/0092070305276149.

Olson, K.2013.National study quantifies reality of the 'Sharing Economy 'movement, retrieved on September10, 2015...com/678_national-study-quantifies-realityof-the-sharing-economy- movement.

PwC. (2015), “The Sharing Economy - Consumer Intelligence Series”, PricewaterhouseCoopers, available at: https://doi.org/10.1145/2890602.2890609.

Quinby, D., \& Gasdia, M. 2014. Share this! Private accommodation and the rise of the new gen renters. Report. PhoCusWright.

Rimer, R. 2017. Why do people choose to stay with Airbnb? Modul Vienna University.

Satama, S., 2014. Consumer adoption of access-based consumption services-Case AirBnB.

Series, C.I., 2015. The Sharing Economy. PricewaterhouseCoopers// [Elektronnyj resurs]. Oficial'nyj sajtURL: https://www. pwc.

So, K.K.F., Oh, H. and Min, S. (2018), “Motivations and constraints of Airbnb consumers: Findings from a mixedmethods approach", Tourism Management, available at: https:/ doi.org/10.1016/j.tourman.2018.01.009.

Sthapit, E. and Björk, P., 2019. Sources of distrust: Airbnb guests' perspectives. Tourism Management Perspectives, 31 , pp.245-253.

Stors, N. and Kagermeier, A. (2015), “Motives for Using Airbnb in Metropolitan Tourism - Why do People Sleep in the Bed of a Stranger?", Regions Magazine, available at: https:// doi.org/10.1080/13673882.2015.11500081.

Sweeney, J.C. and Soutar, G.N. (2001), "Consumer perceived value: The development of a multiple item scale", Journal of Retailing, available at: https:/ / doi.org/10.1016/S0022-4359(01)00041-0.

Tussyadiah, I. P. 2015. An exploratory study on drivers and deterrents of collaborative consumption in travel. In Information and communication technologies in tourism 2015 (pp. 817-830). Springer, Cham.

Tussyadiah, I. P., \& Pesonen, J. (2016a). Drivers and barriers of peer-to-peer accommodation stay-an exploratory study with American and Finnish travellers. Current Issues in Tourism, $1 \mathrm{e} 18$.

Tussyadiah, I. P., \& Pesonen, J. (2016b). Impacts of peer-to-peer accommodation use on travel patterns. Journal of Travel Research, 55(8), 1022e1040.

Tussyadiah, I.P. (2016), "Factors of satisfaction and intention to use peer-to-peer accommodation", International Journal of Hospitality Management, available at: https://doi.org/10.1016/j.ijhm.2016.03.005.

Venkatesh, V., Thong, J.Y. and Xu, X., 2012. Consumer acceptance and use of information technology: extending the unified theory of acceptance and use of technology. MIS quarterly, pp.157-178. 
Walsh, G., Shiu, E., \& Hassan, L. M. (2014). Replicating, validating, and reducing the length of the consumer perceived value scale. Journal of Business Research, 67(3), 260e267.

Xie, K.L., Chen, C., Wu, S., 2016. Online consumer review factors affecting offline hotel popularity: evidence from tripadvisor. J. Travel. Tourism Market. 33 (2), 211-223.

Yang, Z., Jun, M., and Peterson, R.T. (2004), "Measuring customer perceived online service quality", International Journal of Operations \& Production Management, available at: https://doi.org/10.1108/01443570410563278.

Zervas, G., Proserpio, D. and Byers, J. (2014), "The rise of the sharing economy: estimating the impact of Airbnb on the hotel industry." Boston University School of Management Research Paper No. 2013-16.

Zhang, T., Seo, S. and Ahn, J.A. (2019), "Why hotel guests go mobile? Examining motives of business and leisure travelers", Journal of Hospitality Marketing and Management, available at: https://doi.org/10.1080/19368623.2019.1539936.

Zhu, D.H., Wang, Y.W. and Chang, Y.P. (2018), “The influence of online cross-recommendation on consumers' instant cross-buying intention: The moderating role of decision-making difficulty", Internet Research, available at: https://doi.org/10.1108/IntR-05-2017-0211.

Zhu, G., So, K. K. F., \& Hudson, S. 2017. Inside the sharing economy. International Journal of Contemporary Hospitality Management. 